\title{
The Location of the Group Antigen of Group D Streptococcus
}

\author{
By DOROTHY JONES* AND P. M. FRANCES SHATTOCK \\ Department of Microbiology, University of Reading
}

(Received 28 April 1960)

\section{SUMMARY}

Gel-diffusion precipitin tests showed that the Streptococcus group D antigen, as usually demonstrated by ring-precipitin tests, was serologically identical in all four species (Streptococcus faecalis, $S$. faecium, $S$. durans, $S$. bovis). Cell walls of representative cultures of all group D species had a similar chemical composition (determined by chromatograpy) as found by other workers. The one strain of $S$. bovis examined lacked galactosamine which was present in the cell walls of the other group D species. The group D specific antigen was found in the residue (cell contents) after the cell-wall fraction had been removed, unlike the group A specific antigen which forms an integral part of the cell wall.

\section{INTRODUCTION}

As part of a study of serological group D Streptococcus we decided to investigate the nature and location of the group $D$ antigen; this has been little studied. By analogy with groups $\mathbf{A}, \mathbf{B}$, and $\mathrm{C}$ the group $\mathrm{D}$ substance has been assumed to be carbohydrate, but this is by no means certain. Foley \& Wheeler (1945) examined four strains of group D Streptococcus of different serological types; they reported that in three strains the group specific antigen was probably protein and in the fourth strain probably carbohydrate. That the group $D$ antigen is different in nature from the A, B, and C group antigens is also suggested by the work of Maxted (1948) and Swan (1954), who reported that the group antigen of group D streptococci was not as easily released by the action of a streptomyces enzyme as was the group antigen of group A, B and C streptococci. Technical difficulties not generally met in other groups of Streptococcus are often encountered in preparing potent group $\mathbf{D}$ antisera and in the extraction of the group antigen for serological identification of isolates (Shattock, 1949). Several workers have reported strains related physiologically to group D strains which were difficult to classify serologically as group D organisms (e.g. MacPherson, 1953; Higginbottom \& Wheater, 1954; Perry, Wilson, Newland \& Briggs, 1955). To help elucidate these problems we have examined the serological identity of the group antigens derived from representative strains of the four species of Streptococcus within serological groups D (Shattock, 1949, 1955) and have attempted to determine the location of the group antigen in the organism.

McCarty $(1952 a, b)$ showed that the group antigen of group A streptococci was located in the cell wall and was composed of rhamnose and glucosamine. Cummins \& Harris (1956) when analysing the cell walls of various Gram-positive bacteria

* Present address, American Meat Institute Foundation, University of Chicago, U.S.A. 
found that the composition of the cell walls of two cultures of group D strepto cocci was as follows. With Streptococcus faecalis 6782 the cell walls contained rhamnose, galactose, glucose, mannose, glucosamine, galactosamine, unknown hexosamine (identified by Strange, 1956, as muramic acid), alanine, glutamic acid, lysine; with $S$. faecalis $\mathbf{3 7 0}$ the cell walls contained all these compounds except galactose. These results confirmed earlier work of Salton (1952) with the cell wall of $S$. faecalis 6782.

Since Cummins \& Harris (1956) found that the cell walls of the two strains of Streptococcus faecalis which they investigated differed from each other chemically as much as either of them differed from that of cell walls of members of other serological groups of Streptococcus, and since the group antigen of group A Streptococcus is situated in the cell-wall (McCarty, $1952 a, b$ ) we decided to attempt to locate the group D specific substance by fractionating the cocci. We thought that chemical differences in cell-wall composition might be associated with serological differences which might account for the known difficulty in grouping some streptococci which physiologically resemble group D Streptococcus. Since the work reported in this paper was completed, Elliott (1959) recorded that he found the group $D$ antigen in the contents of the streptococcal cell and not in the cell wall.

\section{METHODS}

Organisms and media. The organisms investigated included representatives of all species within serological group D (Streptococcus faecalis, and its varieties; S. faecium; $S$. durans; $S$. bovis; Shattock, 1955). These had been isolated from different sources (see Table 1).

Table 1. Strains of serological group D Streptococcus used

\begin{tabular}{lll}
\multicolumn{1}{c}{ Species } & \multicolumn{1}{c}{ Code } & Source \\
$\begin{array}{c}\text { Streptococcus faecalis } \\
\text { and varieties }\end{array}$ & NCTC 6782, 370, 775 & \\
& Magill & Human faeces \\
N37 (Type 1), S161 (Type 3) & - \\
GB122 (Type 4), N83 (Type 5) & Infant faeces* \\
N8 (Type 8) & - \\
S. faecium & HGH 13, HGH511 & Canned ham \\
& P5 & Pig intestine \\
& S748 & Endocarditis \\
& 2MEC, 4MEC & Gruyère cheese \\
& 60 & River water \\
S. durans & N16 (Type 11) & Silage \\
& Arg 117, 98D, Cu2 & Infant faeces* \\
S. bovis & Pearl 11, Campion & Dried milk \\
& BSO7, L23 & Cow dung \\
& S182 (Type 2), S 194 (Type 12) & Bovine rumen \\
& Infant faeces*
\end{tabular}

Stock cultures were maintained in glucose yeast-extract litmus milk medium containing chalk, stored in the cold $\left(4^{\circ}\right)$ and subcultured every 3 months. All cultures were also preserved by freeze-drying. 
The nutrient medium used throughout was glucose Lemco broth $(\%$, w/v: Evans's peptone, 1; Lab. Lemco, 1; $\mathrm{NaCl}$ (Analar), 0.5; glucose, 0.5).

\section{Serological methods}

Preparation of group-specific antisera in rabbits. Cultures for vaccines were grown for $24 \mathrm{hr}$. at $37^{\circ}$ in glucose Lemco broth, the organisms collected by centrifugation, washed twice in $\mathrm{NaCl}(0 \cdot 85 \%, \mathrm{w} / \mathrm{v})$ and resuspended in $\mathrm{NaCl}(0 \cdot 85 \%)$ to give an optical density equivalent to Brown's tube No. 10 (Burroughs Wellcome and Co. Ltd., Euston Road, London, N.W. 1). Samples of suspensions (6 ml./cup) were shaken with $4 \mathrm{~g}$. ballotini beads (Chance No. 12) in a tissue disintegrator (Mickle, 1948; frequency 50/sec. amplitude $c$. $\frac{1}{2}$ in.) for approximately $1 \mathrm{hr}$. (the rubber stoppers of the cup were covered with cellophan). The total material derived from the disintegrated cocci was used for injection. Vaccines were prepared freshly for each injection and were given at 3- to 4-day intervals, starting with two doses of $0.5 \mathrm{ml}$. followed by $1 \mathrm{ml}$. doses. The number of injections required to produce a potent group antiserum varied greatly from rabbit to rabbit. Each batch of antiserum was tested for potency (approximate reaction-time) by the ring-precipitin test against extracts from a selection of group D streptococci of different serological and biochemical types. A serum which gave well-defined rings within $5 \mathrm{~min}$. was considered satisfactory. Each batch of serum was also tested for group-specificity against extracts of organisms of serological groups $\mathbf{A}$ to $\mathbf{P}$.

Preparation of antigen extracts. Two methods were used. (1) Extraction with $\mathrm{HCl}$ (Lancefield, 1933) as followed by Shattock (1949). (2) Extraction with formamide (Fuller, 1938).

Ring-precipitin tests in liquid media. Tubes with an internal diameter of 2-3 mm. were used; samples of sera were dispensed first into the tubes, antigen extracts were layered on top of the sera; the reaction was allowed to develop at room temperature and the junction of serum and extract was examined for ring formation in diffuse daylight, or against a black background with a standard diffused light.

Gel-diffusion tests. Mansi's (1957) modification of the double gel-diffusion method of Ouchterlony (1953) was used. The antiserum (c. $0 \cdot 1 \mathrm{ml}$.) was contained in a centre well and antigen extracts $(c .0 \cdot 1 \mathrm{ml}$.) were dispensed in six wells arranged equidistantly in a hexagon around the well containing antiserum; the reaction was allowed to proceed at room temperature, and plates were inspected daily for 10 days. Lines developed usually within 2-3 days.

\section{Analysis of cell roalls}

Preparation of cell-wall suspensions. The method of Cummins \& Harris (1956) was used except that trypsin (Allen \& Hanbury) was used as enzyme; this contained some ribonuclease (personal communication from Dr C. S. Cummins).

Hydrolysis. Cell-wall preparations from cocci harvested from $500 \mathrm{ml}$. glucose Lemco broth cultures were used for chromatographic analysis, two-thirds being taken for sugars and hexosamines and one-third for amino acids. For sugars and hexosamines, samples were hydrolysed with $2 \mathrm{~N}-\mathrm{H}_{2} \mathrm{SO}_{4}$. For amino acids samples were hydrolysed with $6 \mathrm{~N}-\mathrm{HCl}$ following the methods of Cummins \& Harris (1956). 
Chromatography. Descending chromatograms were used. For the separation of the hexoses and pentoses the ethyl acetate + acetic acid + water (9:2:2) solvent of Jermyn \& Isherwood (1949) was run on Whatman no. 1 filter paper for $20 \mathrm{hr}$. and developed with aniline phthalate. Good separation of the hexoses and pentoses was obtained.

For hexosamines Fischer \& Nebel's (1956) solvent, pyridine + ethyl acetate + water + acetic acid (5:5:3:1), was used on Whatman no. 1 paper, run for $24 \mathrm{hr}$. and developed with ninhydrin $(0 \cdot 2 \%, \mathrm{w} / \mathrm{v}$, in acetone). A good separation of glucosamine from galactosamine was obtained. Known carbohydrates, $2 \%(w / v)$, in aqueous solution preserved with chloroform were used as markers.

Amino acids were examined by a modification of Wolfe's (1957) method on twodimensional chromatograms on Whatman no. 4 paper: the first solvent was $n$-butanol + methylethylketone + $17 \mathrm{~N}$-ammonia + water $(5: 3: 1: 1, \mathrm{v} / \mathrm{v})$ run for $36 \mathrm{hr}$. and dried for $4 \mathrm{hr}$. at $35^{\circ}$. The second solvent was $n$-butanol + acetic acid + water $(60: 15: 25, v / v)$ which gives a one phase solvent (Smith, 1958). After running for $\mathbf{4 0} \mathrm{hr}$. the chromatogram was developed by dipping quickly through a solution of ninhydrin $(0.2 \%, \mathrm{w} / \mathrm{v})$ in acetone $(95 \%, \mathrm{v} / \mathrm{v})+$ water $(5 \%, \mathrm{v} / \mathrm{v})$, the paper dried and heated at $105^{\circ}$ for 5 min. A good separation was obtained. As markers, known amino acids were used at $0.02 \mathrm{M}$ in isopropyl alcohol $(10 \%, \mathrm{v} / \mathrm{v})$ in water.

\section{RESULTS}

\section{Gel-diffusion precipitin tests}

Specific group antisera were prepared by using representative cultures of all species of serological group D as immunizing strains (Streptococcus faecalis S.161, $S$. faecum HGH 511, S. durans 98D, S. bovis Pearl 11). Antigens were prepared by the $\mathrm{HCl}$ (Lancefield) and formamide (Fuller) extraction methods from $S$. faecalis (3 strains), S. faecium (3 strains), S. durans (2 strains), S. bovis (4 strains). Geldiffusion precipitin tests were set up. The centre well contained antiserum and the antigen extracts were distributed so that adjacent wells contained extracts from different species of group $\mathbf{D}$ streptococci. The resulting lines of precipitate which formed as antigens and antibody diffused towards each other joined to form a continuous line, that is, showed a reaction of identity (Ouchterlony, 1953; Wilson \& Pringle, 1955). This result was obtained with each of the four samples of group D antisera and showed that the preparations of group $D$ antigen from all four species were serologically identical.

\section{Chemical and serological investigations of cell walls}

Cell walls of six cultures representative of all species of Streptococcus within serological group D, prepared by the method of Cummins \& Harris (1956), were examined by paper chromatography. The results are given in Table 2 ; included are the results for the two strains $S$. faecalis $\mathbf{6 7 8 2}$ and $S$. faecalis 370 examined by Cummins \& Harris. The relative amounts of the various components were estimated by the size and intensity of the spots. The major components of the cell walls of $S$. faecalis (3 cultures), S. faecium (1 culture), $S$. durans (1 culture) were rhamnose, glucose, glucosamine, galactosamine, alanine, lysine, and glutamic acid (muramic acid was not tested for). Aspartic acid, serine, glycine, and proline were present 
Table 2. Chromatographic analysis of cell walls of species of Streptococcus of serological group $D$

The number of + signs indicates relative abundance.

Components of
cell walls

Arabinose

Rhamnose

Galactose

Glucose

Mannose

Glucosamine

Galactosamine

Aspartic acid

Alanine

Glutamic acid

Glycine

Lysine

Proline

Serine
S. faecalis

$\begin{array}{ccc}\mathbf{6 7 8 2} & \mathbf{3 7 0} & \mathbf{7 7 5} \\ - & - & - \\ ++ & ++ & ++ \\ + & - & + \\ ++ & ++ & ++ \\ + & + & + \\ ++ & ++ & ++ \\ + & + & + \\ + & + & + \\ +++ & +++ & +++ \\ ++ & +++ & +++ \\ + & + & + \\ ++ & +++ & +++ \\ + & + & + \\ + & + & +\end{array}$

S. durans 4MEC 98D Pearl 11

S. bovis

$\begin{array}{ccc}- & - & - \\ ++ & ++ & ++ \\ - & + & + \\ ++ & ++ & ++ \\ - & - & - \\ ++ & ++ & ++ \\ + & + & - \\ + & + & + \\ +++ & +++ & +++ \\ +++ & +++ & +++ \\ + & + & + \\ +++ & +++ & +++ \\ + & + & + \\ + & + & +\end{array}$

in small quantities. One culture of $S$. bovis showed the same pattern except that galactosamine was not detected.

Serology. From cell walls of Streptococcus faecalis 6782 and 370, S. faecium 4. MEC, $S$. durans $98 \mathrm{D}$ extracts $(\mathrm{HCl}$, Lancefield; for amide, Fuller) were prepared and tested by the ring-precipitin test against group $\mathbf{D}$ antisera prepared against S. faecalis, S161, S. durans 98D, S. faecium HGH511 and S. bovis Pearl 11 and against a sample of commercial group $D$ antiserum. The only cell-wall extracts which gave any group reactions were those prepared from $S$. faecalis 6782 , where weak precipitin rings were obtained with the five group antisera (Table 3).

Table 3. $\mathrm{HCl}$ (Lancefield) and formamide (Fuller) extracts of cell walls of Streptococcus group $D$ tested against five samples of group $D$ antisera by ring-precipitin and geldiffusion tests

Group D antisera against immunizing strains

\begin{tabular}{|c|c|c|c|c|c|c|c|c|c|c|}
\hline \multirow[t]{2}{*}{$\begin{array}{l}\text { Extracts of cell } \\
\text { walls of }\end{array}$} & \multicolumn{2}{|c|}{ S. faecalis } & \multicolumn{2}{|c|}{ S. faecium } & \multicolumn{2}{|c|}{ S. durans } & \multicolumn{2}{|c|}{ S. bovis } & \multicolumn{2}{|c|}{$\begin{array}{c}\text { Commercial } \\
\text { serum }\end{array}$} \\
\hline & $\mathbf{L}^{*}$ & $\mathbf{F} \dagger$ & $\mathbf{L}$ & $\mathbf{F}$ & $\mathbf{L}$ & $\mathbf{F}$ & $\mathbf{L}$ & $\mathbf{F}$ & $\mathbf{L}$ & $\mathbf{F}$ \\
\hline S. faecalis 6782 & \pm & \pm & \pm & \pm & \pm & \pm & \pm & \pm & \pm & \pm \\
\hline 370 & - & - & - & - & - & - & - & - & - & - \\
\hline S. faecium 4MEC & - & - & - & - & - & - & - & - & - & - \\
\hline S. durans 98D & - & - & - & - & - & - & - & - & - & - \\
\hline
\end{tabular}

$\pm=$ weak precipitin ring; $-=$ no precipitin $\operatorname{ring} ; \mathrm{L}^{*}=\mathrm{HCl}$ (Lancefield) extracts $; \mathrm{F} \dagger=$ formamide (Fuller) extracts.

At this stage in the work the method of preparing cell walls was modified by omitting treatment with pepsin. Chromatographic analyses showed no difference between the chemical composition of the cell walls prepared by digestion with trypsin, containing ribonuclease, and pepsin, and that of cell walls prepared by omitting pepsin treatment. With the same strains as in the previous experiment, together with Streptococcus bovis BSO7, the serological activity of cell walls prepared without pepsin treatment was tested. $\mathrm{HCl}$ (Lancefield) extracts of cell walls and of 
whole organisms were compared by ring-precipitin tests against group D antisera prepared with the immunizing strains used in the previous experiment. Similar results were obtained. $\mathrm{HCl}$ extracts of whole organisms all gave clear-cut group precipitin rings, while $\mathrm{HCl}$ extracts of the corresponding cell-wall preparations gave no group ring precipitin reactions with the single exception of $S$. faecalis 6782 , which again reacted weakly with the grouping sera. The absence of group antigen from the cellwall preparations was again confirmed by gel-diffusion tests. The group $\mathbf{D}$ antigen was not detected in cell walls from $S$. faecalis 6782 by gel diffusion.

\section{The location of the group $D$ antigen}

Because of the unexpected finding that the group $\mathbf{D}$ antigen was apparently not situated in the cell wall the following experiments were devised to test this further. $\mathrm{HCl}$ extracts were prepared from cell walls of a larger number of group D strains (Streptococcus faecalis, 6;S. faecium, 6;S. durans, 4;S. bovis, 4) and compared with $\mathrm{HCl}$ extracts of whole organisms, twice as many organisms being used to prepare the cell-wall extract. (It was thought that the apparent absence of the group $D$ substance from the cell-wall preparations first used might have been due to a loss of organisms or cell walls during the preparation of the cell-wall suspensions.) Cultures were grown in $\mathbf{1 2 0} \mathrm{ml}$. glucose Lemco broth, the organism centrifuged down and washed twice with distilled water. One-third of the washed

Table 4. A comparison of $\mathrm{HCl}$ (Lancefield) extracts of whole organisms and of cell walls by ring-precipitin and gel-diffusion tests with four samples of group $\boldsymbol{D}$ antisera

Immunizing strains for the preparation of antisera were $S$. faecalis, $S$. faecium, $S$. durans, $S$. bovis

Antigens $\begin{aligned} & \text { No. strains } \\ & \text { tested } \\ & \text { Whole organisms }\end{aligned} \overbrace{\begin{array}{c}\text { Ring-precipitin } \\ \text { test }\end{array}}^{\text {Group D antisera }} \overbrace{\begin{array}{c}\text { Gel-diffusion } \\ \text { test }\end{array}}^{\text {D }}$

S. faecalis
S. faecium
S. durans
S. bovis

S. faecalis

S. faecium

S. durans

S. bovis

$\begin{array}{ll}\mathbf{6} & + \\ \mathbf{6} & + \\ \mathbf{4} & \\ \mathbf{4} & \end{array}$

Cell walls

$+=$ heavy ring of precipitate within 5 min. or line of precipitate in gel-diffusion test.

$\mathbf{t r}=$ weak delayed reaction.

$-=$ no reaction.

organisms were extracted with $\mathrm{HCl}$ (Lancefield) and two-thirds were used for the preparation of cell walls. $\mathrm{HCl}$ extracts of cell walls and of whole organisms were compared by ring-precipitin and gel-diffusion tests against four samples of group D antisera. No group antigen was demonstrated in the preparations of cell wall from $S$. faecium, $S$. durans, $S$. bovis or 3 out of 6 strains of $S$. faecalis. With the $\mathrm{HCl}$ extracts of cell walls from the other three strains of $S$. faecalis, weak delayed precipitin rings were observed; these were insignificant as compared with the reactions obtained 
with $\mathrm{HCl}$ extracts of whole organisms which, for every strain examined, gave clearcut rapidly formed rings. Tests in gel-diffusion plates confirmed the presence of group $\mathbf{D}$ antigen in whole organisms and its absence from the cell-wall preparations. No lines of precipitate were given by any cell-wall extract. The results are summarized in Table 4.

The action of trypsin (Allen \& Hanbury) on the group D antigen in whole organisms was examined with 20 strains (Streptococcus faecalis, 6; S. faecium, 6; S. durans, $4 ; S$. bovis, 4$)$. Whole organisms treated with trypsin (as in preparation of cell walls) were extracted with $\mathrm{HCl}$ and the extracts compared with $\mathrm{HCl}$ extracts of whole untreated organisms by the ring-precipitin test against a group $\mathrm{D}$ antiserum. $\mathrm{HCl}$ extracts of whole organisms and of trypsin-treated organisms gave precipitin rings of similar intensity. $\mathrm{HCl}$ extracts from 9 of these strains were also compared by geldiffusion tests, with similar results. Therefore treatment with trypsin did not destroy or release group $\mathbf{D}$ antigen from intact organisms.

Table 5. Comparison of $\mathrm{HCl}$ (Lancefield) extracts of whole organisms and $\mathrm{HCl}$ (Lancefield) extracts of cell walls and cell contents against four samples of group $D$ antisera by ring-precipitin and gel-diffusion tests

Immunizing strains of the preparation of antisera were $S$. faecalis, S. faecium, S. durans, S. bovis.

\begin{tabular}{|c|c|c|c|}
\hline \multirow[b]{2}{*}{ Antigens } & \multirow{2}{*}{$\begin{array}{l}\text { No. of } \\
\text { strains } \\
\text { tested }\end{array}$} & \multicolumn{2}{|c|}{ Group D antisera } \\
\hline & & $\underset{\text { Ring-precipitin }}{\text { Rin }}$ & $\begin{array}{c}\text { Gel-diffusion } \\
\text { test }\end{array}$ \\
\hline \multicolumn{4}{|c|}{ Whole organisms } \\
\hline S. faecalis & 6 & $+t$ & + \\
\hline S. faecium & 6 & $+t$ & + \\
\hline S. durans & 4 & ++ & + \\
\hline S. bovis & 2 & + & + \\
\hline \multicolumn{4}{|c|}{ Cell contents } \\
\hline S. faecalis & 6 & +++ & + \\
\hline S. faecium & 6 & $t+t$ & + \\
\hline S. durans & 4 & $+t+$ & + \\
\hline S. bovis & 2 & + & + \\
\hline \multicolumn{4}{|c|}{ Cell walls } \\
\hline S. faecalis & 6 & $-/ \operatorname{tr}$ & - \\
\hline S. faecium & 6 & $-\mathrm{tr}$ & - \\
\hline S. durans & 4 & - & - \\
\hline S. bovis & 2 & - & - \\
\hline
\end{tabular}

Since the group antigen did not appear to be present in the cell walls of group D streptococci, we examined the supernatant fluid from disintegrated organisms which had hitherto been discarded after centrifuging down the cell-wall fraction. This supernatant fluid will be referred to as the 'cell contents'. The cell contents of organisms from 18 cultures were tested against four samples of group D antisera by ring-precipitin and gel-diffusion tests. A comparison was also made with $\mathrm{HCl}$ extracts of whole organisms and $\mathrm{HCl}$ extracts of cell walls from samples of the same batches of organisms as used for preparing cell contents. With all the strains of 
group D streptococci tested the group antigen was found in the cell contents (Table 5). The group $\mathrm{D}$ antigen in the preparations of cell contents was shown by gel-diffusion tests to give a reaction of identity with the group antigen extracted by $\mathrm{HCl}$ from the whole organism when tested against group $\mathrm{D}$ antisera.

\section{DISCUSSION}

In strains of Streptococcus of serological group $\mathbf{A}$ the group specific antigen is a polysaccharide which forms an integral part of the cell wall. It now appears that in contrast to this the group $\mathrm{D}$ specific antigen is in the residue after the cell wall has been removed; these results agree with Elliott's (1959) observations. He recorded that for five group D cultures of Streptococcus of different serological types, the cell walls contained type-specific antigen and the group-specific antigen was found in the cell contents and not in the cell walls. Glucose was the only sugar detected by paper chromatography in the group-specific antigen obtained from the cell contents of a strain of $\boldsymbol{S}$. durans. In passing we note that a preliminary chromatographic analysis of the crude group $\mathbf{D}$ antigen precipitated by acetone from the cell contents of our strain of $S$. durans $98 \mathrm{D}$ showed the presence of glucose and ribose, the latter possibly from contaminating nucleic acid.

From the results of our experiments reported here it seems that the specific group D antigen is located in the cytoplasm of group D Streptococcus. The possibility is not yet ruled out that it may be loosely attached to the cell wall and hence separated by the method of disintegration. But with every strain of group D Streptococcus examined the cell contents contained amounts of specific group $\mathbf{D}$ antigen at least as much as that obtained in extracts from comparable numbers of whole organisms, as estimated by the intensity of ring-precipitin reactions. A few samples of cell walls showed a slight serological group $\mathbf{D}$ activity by the ringprecipitin test but not by gel-diffusion tests. It seems likely that these cell-wall preparations were slightly contaminated with the group specific antigen from the cell contents. The group D specific antigen does not appear to form an integral part of the cell wall, as does the group A polysaccharide. The presence of the group D antigen in cell contents from which the cell-wall fraction has been removed helps to explain Shattock's (1949) observation that group D antisera are more readily prepared in rabbits by using as vaccine disintegrated rather than whole organisms. It is also consistent with our experience that nutritional conditions play an important role in the synthesis of group $D$ substance as distinct from their effect on multiplication. A medium which supports good growth does not necessarily result in good quantitative production of group $\mathrm{D}$ antigen.

We are indebted to Dr Ella M. Barnes, Dr C. A. E. Briggs, Dr A. E. Oxford and Dr M. Elisabeth Sharpe for providing cultures. A grant from the Agricultural Research Council in support of this work is gratefully acknowledged.

\section{REFERENCES}

Cummins, C. S. \& Harris, H. (1956). The chemical composition of the cell wall in some Gram-positive bacteria and its possible value as a taxonomic character. J. gen. Microbiol. 14, 583.

ELLIOTT, S. D. (1959). Group and type-specific polysaccharides of group D streptococci. Nature, Lond. 184, 1342. 
Fischer, F. G. \& Nebel, H. J. (1956). Detection and estimation of glucosamine and galactosamine on paper chromatograms. Anal. Abst. 3, 1101.

Foley, G. E. \& WheEler, S. M. (1945). Studies on the streptococci (enterococci) of Lancefield group D. I. Serologic and biochemical characteristics. Amer. J. Dis. Child. 70, 93.

Fuller, A. T. (1938). The formamide method for the extraction of polysaccharides from haemolytic streptococci. Brit. J. exp. Path. 21, 130.

Higginbottom, C. \& Wheater, D. W. F. (1954). The incidence of Streptococcus bovis in cattle. J. Agric. Sci. 44, 434.

Jermyn, M. A. \& Isherwood, F. A. (1949). Improved separation of sugars on the paper partition chromatogram. Biochem. J. 44, 402.

LANCEFIELd, R. C. (1933). A serological differentiation of human and other groups of haemolytic streptococci. J. exp. Med. 57, 571.

MacPherson, M. J. (1953). Isolation and identification of amylolytic streptococci from the rumen of sheep. J. Path. Bact. 66, 95.

MaNSI, W. (1957). The study of some viruses by the plate gel diffusion precipitin test. J. comp. Path. 67, 297.

MaXted, W. R. (1948). Preparations of streptococcal extracts for Lancefield grouping. Lancet, ii, 255.

McCarty, M. (1952a). The lysis of group A streptococci by extracellular enzymes of Streptomyces albus. 1. Production and fractionation of the lytic enzymes. J. exp. Med. 96, 555.

MCCARTY, M. (1952b). The lysis of group A streptococci by extracellular enzymes of Streptomyces albus. II. Nature of the cellular substrate attacked by the lytic enzymes. J. exp. Med. 96, 569.

Mickle, H. (1948). Tissue disintegrator. J.R. micr. Soc. 68, 10.

Ouchterlony, O. (1953). Gel diffusion methods for immunological analysis. Atti 6 Congr. int. Microbiol. Roma, 2, 276.

Perry, K. D., Wilson, M. K., Newland, L. G. M. \& Briggs, C. A. E. (1955). The normal flora of the bovine rumen. III. Quantitative and qualitative studies of rumen streptococci. J. appl. Bact. 18, 436.

Salton, M. R. J. (1952). Studies of the bacterial cell wall. III. Preliminary investigation of the chemical constitution of the cell wall of Streptococcus faecalis. Biochim. biophys. $a c t a, 8,510$.

Sharpe, M. E. \& Shatrock, P. M. F. (1952). The serological typing of group D streptococci associated with outbreaks of neonatal diarrhoea. J. gen. Microbiol. 6, 150.

Shatтock, P. M. F. (1949). The streptococci of group D; the serological grouping of Streptococcus bovis and observations on serologically refractory group D strains. J. gen. Microbiol. 3, 80.

Shatrock, P. M. F. (1955). The identification and classification of Streptococcus faecalis and some associated streptococci. Ann. Inst. Pasteur, Lille, 7, 95.

Sмттн, I. (1958). Chromatographic techniques. Clinical and Biochemical Applications, p. 60. London: William Heinemann Medical Books Ltd.

Strange, R. E. (1956). The structure of an amino sugar present in certain spores and bacterial cell walls. Biochem. J. 46, 23 P.

Swan, A. (1954). The use of a bile-aesculin medium and of Maxted's technique of Lancefield grouping in the identification of enterococci (Group D streptococci) J. clin. Path . 7,160 .

Wilson, M. W. \& Pringle, B. H. (1955). Interpretation of Ouchterlony precipitin test. J. Immunol. 75, 460.

Wolfe, M. (1957). The quantitative determination of aminoacids by paper chromatography. A solvent to replace phenol. Biochim. biophys. Acta, 23, 186. 